\title{
Thyroid Disrupting Activities in Wastewater and Surface Waters: A Review of Their in Vitro Analyses
}

\author{
Maurice Eghosa Imiuwa ${ }^{1}$, Abraham Ogheneruemu Ekperusi² \\ ${ }^{1}$ Department of Animal and Environmental Biology, Faculty of Life Sciences, University of Benin, Benin City, Nigeria \\ ${ }^{2}$ Department of Marine Environment and Pollution Control, Faculty of Marine Environmental Management, \\ Nigeria Maritime University, Okerenkoko, Delta State, Nigeria \\ Email: maurice.eghosa@uniben.edu
}

How to cite this paper: Imiuwa, M.E. and Ekperusi, A.O. (2019) Thyroid Disrupting Activities in Wastewater and Surface Waters: A Review of Their in Vitro Analyses. Journal of Environmental Protection, 10, 1131-1143. https://doi.org/10.4236/jep.2019.109067

Received: July 12, 2019

Accepted: September 9, 2019

Published: September 12, 2019

Copyright $\odot 2019$ by author(s) and Scientific Research Publishing Inc. This work is licensed under the Creative Commons Attribution International License (CC BY 4.0).

http://creativecommons.org/licenses/by/4.0/

\begin{abstract}
The developmental and reproductive effects of endocrine disruption on humans and wildlife rank among the most threatening of all environmental health concerns. Particularly vulnerable to chemical assaults are the hypothalamic-pituitary-gonadal (HPG) axis and the hypothalamic-pituitary-thyroid (HPT) axis of the endocrine system. While the effects of endocrine disrupting chemicals (EDCs) on the HPG axis have been the subject of intense research efforts, with comprehensive elucidation, a lot remains to be clarified on the effects of EDCs on thyroid functions. For instance, there are no clear-cut biomarkers of exposure and effects of thyroid disrupting chemicals (TDCs) in intact organisms. Consequently, a number of in vitro assays have been developed, and are particularly useful for the identification and mechanistic characterization of potential TDCs considering the increasing number of EDCs that are being released into the environment. However, with the in vitro assays, studies suggest that a plausible major mode of action of TDCs, thyroid hormone receptor (THR) agonist activity, is not environmentally relevant. Here, we reviewed in vitro detection of TDCs activities in wastewater and surface waters. Data strongly suggest that cell lines may be responsible for the less frequent detection of THR agonist activity in wastewater and surface water. It was concluded that the development of reporter gene assays with thyroid hormone function related cell lines, is required.
\end{abstract}

\section{Keywords}

Thyroid Disruption, Thyroid Activities in Wastewater and Surface Water, Thyroid Receptor Agonist Activity, In Vitro Analysis, Reporter Gene Assays 


\section{Introduction}

The impact of endocrine disrupting chemicals (EDCs) on biological systems is foremost of all environmental health concerns [1]. EDCs are known to adversely disrupt hormonal regulations of many critical physiological processes. These critical biological process disruptions have been demonstrated to result in various adverse developmental and reproductive effects in humans and wildlife. Additionally, a number of EDCs have been shown to act through multiple pathways in the endocrine system [2].

The hypothalamic-pituitary-gonad axis, and the hypothalamic-pituitary-thyroid axis are two major axes of the endocrine system that are particularly vulnerable to exogenous chemical assault owing to their delicate intricate cascade of cellular and molecular regulation of physiological functions [3] [4]. However, while the effects of EDCs on the HPG axis have been considerably investigated and comprehensively described, a lot remains to be clarified on the effect of EDCs on the HPT axis, principally involving the thyroid hormone system [5] [6].

Particularly elusive, is the development of a clear-cut biomarker of exposure and effects of thyroid disruptions in intact organisms [7] [8]. Consequently, detection of thyroid active anthropogenic chemicals otherwise known as thyroid disrupting chemicals (TDCs) relies, for the most part, on the use of in vitro assay [9] [10]. However, with the in vitro detection approach, it appears that a possible major mode of actions of TDCs, thyroid receptor activation, is not environmentally relevant. Further, while the reason for this is not yet clear, and particularly challenging, performance limitation of in vitro assays is highly probable, given the inherent cell type-induced variations in the sensitivity of the widely used in vitro assays to potential TDCs [6] [11].

The numbers of toxic chemicals that are being released into the environment, especially surface waters, are disturbingly on the increase [12] [13]. Of these chemicals, a wide spectrum has been shown to possess various (anti)thyroid activities in wastewater and surface waters, posing serious developmental threats to wildlife and humans. Considering the leading role of the thyroid hormones in development in humans and wildlife [4], and the magnitude of developmental adverse outcome associated with thyroid disruption, we here reviewed studies on thyroid disrupting activities in wastewater and surface waters, and proposed the development of assays with thyroid functions related cell lines for improved in vitro detection of thyroid disruption involving thyroid receptor (TR) signaling pathways.

\section{Thyroid Hormones}

Thyroid hormones (TH) produced by the thyroid gland, are principally responsible for the permissive regulation of a number of key physiological processes such as development, reproduction, metabolism, cellular proliferation, differentiation and development of the central nervous system [14] [15]. The vertebrate thyroid gland produces two iodine-containing hormones derived from the ami- 
no acid, tyrosine. The hormones are tetraiodothyronine (T4 or thyroxine) and triiodothyronine (T3) [14].

T4 is synthesized in the thyroid gland and converted (bioactivation) to T3 outside the gland through the action of the enzyme, deiodinase, which catalyzes the removal of one iodine residue from T4 [16]. Thus, while T4 is the primary hormone, the short-lived T3 is the more active form (Figure 1), which influences development and metabolism related gene expression in almost all tissues of the body [14]. The hormones are transported bound to specific transport proteins to target tissues where their actions are mediated by thyroid hormone receptors (TRs) derived from two distinct genes widely distributed in the animal kingdom [17].

All vertebrates, and some invertebrates despite the obvious absence of the thyroid gland, produce thyroid hormones [18]. The ubiquitous presence of thyroid disruptors in the aquatic environment is therefore a major threat to humans and wildlife. Commonly reported thyroid system disruptions include thyroid hormone synthesis inhibition, TH displacement from transport protein, antagonistic and agonistic binding of TDCs to thyroid receptors, and in some cases, modulation of thyroid hormone-dependent gene expression [19].

\section{In Vitro Assays for (Anti)Thyroid Activities Detection}

In vitro assays provide cell models for practically all tissues or laboratory animals [9], and are particularly useful for mechanistic insight into toxicity [20]. Currently, very little is known about thyroid disruption especially in terms of the development of clear-cut biomarkers of exposure and effects in intact organism.

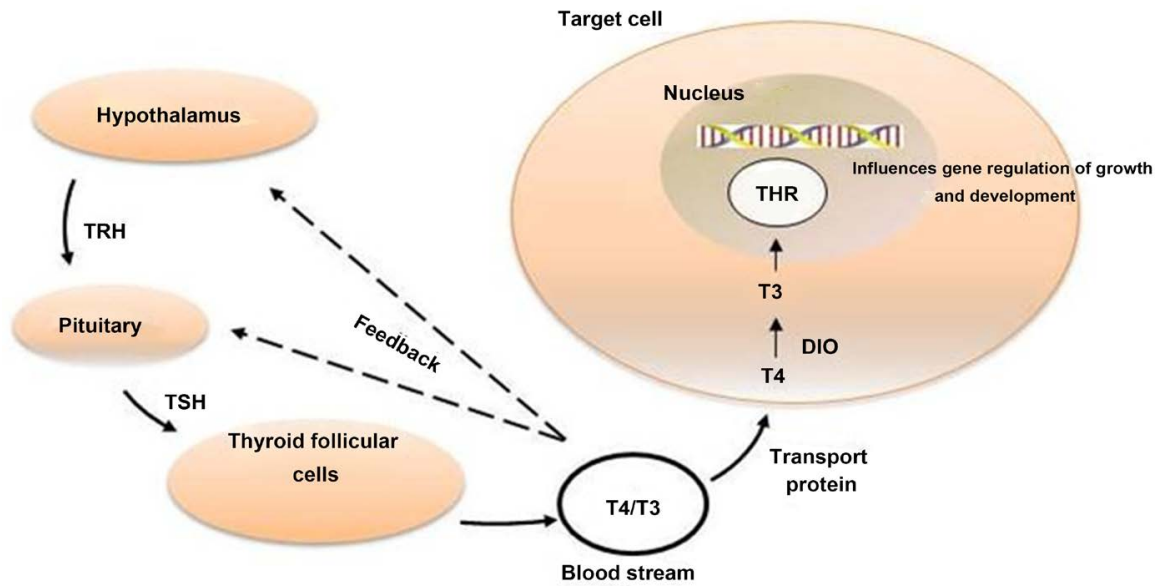

Figure 1. A simplified schematic representation of the hypothalamus-pituitary-thyroid axis. The hypothalamus produces the thyrotropin-releasing hormone (TRH), which stimulates the pituitary gland to produce thyroid stimulating hormone (TSH). TSH in turn stimulates the thyroid to produce thyroid hormone (TH). In mammals, TH, produced directly from the thyroid gland is predominantly T4 (with some T3), whereas in some non-mammalian vertebrates, T4 is produced. Usually, T3 is the biologically active form, and it is produced through the deiodination of $\mathrm{T} 4$ by the action of deiodinase (DIO). To exert its physiological effects, T3 binds to thyroid hormone receptor (THR) in the target cells for thyroid hormone-dependent gene expression. 
In vitro analysis of thyroid disrupting activities in wastewater and surface waters, for at least the identification and mechanistic characterization of potential TDCs, can therefore not be dispensed with considering the critical role of thyroid in the regulation of development in almost all tissues of the body.

Detection of thyroid disrupting activities has employed different aspects of thyroid system, including thyroid hormone biosynthesis, secretion and transport, metabolism and excretion, local cellular concentration, and cellular responses [21]. Of these however, thyroid hormone transport and cellular responses, are the ones that are widely considered within thyroid hormone system in environmental water samples, usually involving displacement assays, and ligand binding and reporter gene assays respectively [17].

The displacement assays measure the potency of a contaminant to displace T4 from thyroid hormone transport proteins such as transthyretin (TTR) and thyroxine-binding globulin (TBG). Three major displacement assays; raido-ligand binding assay, plasmon resonance-based biosensor assay and the fluorescence displacement assay, are commonly used [19]. Briefly, the radio-ligand binding assay (RBA) uses radioactive T4, which is usually in equilibrium with TTR, T4 and the chemical to be tested. The amount of free radio-labelled T4 is a measure of the contaminant (competitor) displacement or binding potency. The plasmon resonance-based biosensor is designed to use immobilized T4, which is able to interact with a mobile phase containing TTR or TBG and the chemicals to be tested (competitor). The proportion of the free TTR or TBG available for binding the immobilized T4 is a measure of the displacement or binding potency of the contaminants. The fluorescence displacement assay uses fluorescence emitted from a flourophore when displaced from a transport protein by the competitor [19] [22].

The ligand binding assays measure the potency of a chemical to interfere with TRs. The procedure typically measures the inhibitory ability of a chemical (competitor) on the binding of radio-labelled T3 to TRs expressed in the nuclear fraction of a select cell line. Here, the nuclear fraction, which is the nuclear component of the cell line expressing TRs, is isolated and incubated with the test chemical and radio labelled T3, and the radiolabelled T3 bound to TR is determined. The displacement by the test chemical of the radio-labelled T3 bound TR is a measure of their affinity to TR [23]. The alternative approach, the reporter gene assays, usually involves the use of cell lines that are stably or transiently transfected with TR (if not constitutively expressed), thyroid hormone response element (TRE) and TRE responsive reporter gene. This assay measures the activity or expression of the reporter gene, which is indicative of the potency of test the chemical to activate TR [23] [24]. Thus, the ligand binding assays and the reporter gene assays both measure TR-mediated disruption of TH signaling.

Studies show that TR-mediated disruption of TH signaling is a major mode of action of TDCs in wastewater and surface waters, and TDCs with potential to interfere with TRs can either act as antagonists, repressing the receptor upon binding 
to it or as agonists when they are able to activate the receptor upon binding the receptor [6]. However, while TR binding assays and reporter gene assays can both detect TDCs with potential to interfere with TR, only reporter gene assays can discriminate between agonist and antagonist activities. Currently, TR binding assays, and a variety of reporter gene assays usually with different cell line types [11], are majorly used in the detection of thyroid disrupting activities in wastewater and surface waters.

\section{In Vitro Detection of Thyroid Disrupting Activities in Wastewater and Surface Waters}

Evaluating the thyroid disrupting activity in effluents of two paper manufacturing plants (PMPs) in Songkhla province, and canal Khlong U-Tapahao, Thailand, Ishihara et al. [12] using TR binding assay, XL58-TRE-luc reporter gene assay and TTR displacement assay observed $30 \%$ to $40 \%$ inhibition of radio-labelled T3 binding to TTR in the PMPs wastewater samples, and 90\% inhibition in TR binding assay of samples from one of the PMPs before treatment. In the canal water samples, thyroid disrupting activities were also detected with 65\% (TTR binding assay), 96\% (TR binding assay) and 54\% (XL58-TRE-luc assay) inhibition at location 1; 44\% (TR binding assay) and 50\% (XL58-TRE-luc assay) inhibition at location 2; 55\% (TR binding assay) and 44 (XL58-TRE-luc assay) inhibition at location 3; and 7\% (TTR binding assay) and 87\% (XL58-TRE-luc assay) inhibition at location 4 . TR-agonist activity was not detected in any of the samples analyzed.

In samples from sewage treatment plants, Japan, Murata and Yamauchi [25] observed inhibition of radiolabelled T3 binding to TR and TTR, with higher sensitivity in TR binding assay. Further, some sample extracts elicited T3-like activity in XL58-TRE-Luc reporter gene assay, which however, was not detected when the extract was spiked with $2 \mathrm{nM}$ of T3. In a parallel assessment of thyroid and estrogen disruptors in samples from wastewater treatment plants (WWTPs), river Seine and drinking water supplies in Paris area, France, Jugan et al. [26] observed weak thyroidal activity only in the influents of WWTPs using the DR-PC-Luc assay with $25 \mathrm{ng} / \mathrm{L}$ T3 Equivalent (ThEQ). Additionally, they reported that thyroid disrupting activity was either too weak or below detection limit in the effluent samples analyzed. In contrast, Li et al. [27] observed TR antagonistic activity in extracts of both effluent and source water samples with a two-hybrid yeast assay in a waterworks in Beijing, China. The bioassay-derived $\mathrm{NH} 3$ equivalence of sample's antagonistic activity (NH3-EQbio), ranged from $180.8 \pm 24.8$ to $280.2 \pm 48.2 \mu \mathrm{g} / \mathrm{L}$ NH3. Similarly, in extracts of samples from three wastewater treatment plants (WWTPs) in Beijing, Li et al. [28] detected only TR-antagonistic activity with a two-hybrid yeast assay. Calculated relative to a known TR-inhibitor, amiodarone hydrochloride (AH), the TR-antagonistic potencies in the effluents from the three WWTPs before treatment and in the receiving rivers respectively, were $6.19 \times 10^{-7}$ and $2.35 \times 10^{-8} \mathrm{~mol} \mathrm{AH}-\mathrm{EQ} / \mathrm{L}$ 
(WWTP 1); $8.75 \times 10^{-8}$ and $3.76 \times 10^{-8} \mathrm{~mol} \mathrm{AH-EQ/L} \mathrm{(WWTP} \mathrm{2);} \mathrm{and} 2.55 \times$ $10^{-8}$ and $4.80 \times 10^{-9} \mathrm{~mol} \mathrm{AH-EQ/L}$ (WWPT 3).

On thyroid disrupting activities in extracts of surface water samples, Shi et al. [29] detected antagonistic potency ranging from 3.2 to $8.2 \mu \mathrm{g}$ DNPB EQs/L (calculated relative to dibutylphthalate) in a concentration dependent manner in 4 of 5 extracts analyzed in eastern China with green monkey kidney fibroblast (CV-1) cell based reporter gene assay. None of the samples analyzed showed TR agonistic potency. Shi et al. [30], also using the CV-1 cell based reporter gene assay, detected TR antagonistic potency ranging from 1.4 to $5.6 \mu \mathrm{g}$ din-butyl phthalate/L in a concentration-dependent manner in all water source extracts from Yangtze River Delta, Shanghai. Agonistic potency was expectedly not detected in the extracts analyzed. Using CV-1 cell based reporter gene assay, Shi et al. [31] observed in samples from lower reaches of the Yangtze and Huai Rivers, and Tai Lake, China, TR antagonist potencies with equivalent potency values ranging from 3.6 to $76.1 \mu \mathrm{g}$ dibutylphthalate /L. Agonistic potency was also not observed in the surface water samples analyzed. Recently, Leusch et al. [6] while comparing in vitro and in vivo analyses of thyroid disrupting activity in environmental samples including surface water and treated wastewater from the river Rhine at Karlsruhe, Germany, observed that unspiked water extracts from treated wastewater and surface water resulted in thyroperoxidase (TPO) inhibition, and had a significant effect on TTR displacement assay. Further, using GeneBLazer reporter gene assay, extract of treated wastewater caused significant inhibition with an amiodarone equivalent concentration (AmiEQ) of $350 \mu \mathrm{g} / \mathrm{L}$. Agonistic potency was also not detected as none of the unspiked samples revealed agonistic activity.

Interestingly, Shi et al. [32] detected TR agonist activity, ranging from 286 to $293 \mathrm{ng}$ T3/L only in 3 of 11 source water samples from Yangtze River, China, analyzed with a green monkey kidney fibroblast (CV-1) cell based TH reporter gene assay. Further, antagonistic activity calculated relative to dibutyl phthalate (DBP) (51.5 to $555.3 \mu \mathrm{g} / \mathrm{L}$ Ant-TR-EQs), was however also detected in all water source samples. Shi et al. [33] similarly observed weak agonist potency only in 1 of 15 surface water samples from Yangtze River Delta, China, analyzed with $\mathrm{CV}-1$ cell-based $\mathrm{TH}$ reporter gene assay while investigating thyroid disrupting activity associated with phthalates. TR antagonistic potency $\left(2.8 \times 10^{1}\right.$ to $1.6 \times$ $10^{3} \mu \mathrm{g}$ DBP/L) was also detected in most of the surface water samples analyzed. In surface water adjacent to impoundment at West Virginia, US, Kassotis et al. [34] detected weak TR agonist activity with a mammalian reporter gene assay in addition to TR antagonist potency. The observed TR-agonist and antagonist potencies were $5 \mu \mathrm{g}$ and $700 \mu \mathrm{g}$ T3-equivalent per litre water respectively. Overall, these studies suggest that TR agonist activity in environmental water samples is not environmentally relevant, and this a major environmental health concern considering the number of different chemicals that have been implicated in thyroid disruption in laboratory studies. 


\section{Chemicals Implicated in Thyroid Disrupting Activities in Wastewater and Surface Waters}

Thyroid disrupting chemicals (TDCs) have been defined as xenobiotics that alter the structure or functions of the thyroid gland, alter regulatory enzymes associated with thyroid hormone homeostasis, or change circulating or tissue concentration of thyroid hormone (Figure 2) [21]. It is not surprising that a wide range of chemicals have been implicated in thyroid hormone system disruption considering the ubiquity of anthropogenic chemicals in environmental matrix, and the vulnerability of the endocrine system to chemical assaults [3] [27]. Additionally, structural resemblance of many anthropogenic chemicals to $\mathrm{TH}$ has often resulted in enlisting them as model or suspected TDCs. Nonetheless, in dealing with classification and characterization of potential TDCs in the environment, environmental occurrence with (anti)thyroid activity is a major factor [3] [15].

In a parallel assessment of thyroid disrupting activities and the identification of its major contributors in surface waters, phthalates, including di-n-butyl phthalate (DNBP), diisobutyl phthalate (DNOP) and di-2-ehtylhexyl phthalate (DEHP) [30]; and organochlorine compounds including hexachlorocylohexane $(\mathrm{HCH})$, dichlorodiphenyltrichloroethane(DDT) and chlordane [29] [33] were identified as the responsible thyroid active chemicals in the samples analysed. Further, also demonstrated to have potential to interfere with the TH system in vitro, are several industrial chemicals including Polychlorinated biphenyls (PCBs) [35] [36], Bisphenol A (BPA) [37] [38], polybrominateddiphenylethers (PBDEs) [19], triclosan (TCs) [39] and perchlorate $\left(\mathrm{ClO}_{4}^{-}\right)$[40] with reported occurrence in wastewater and surface waters [15] [39] [41] [42].

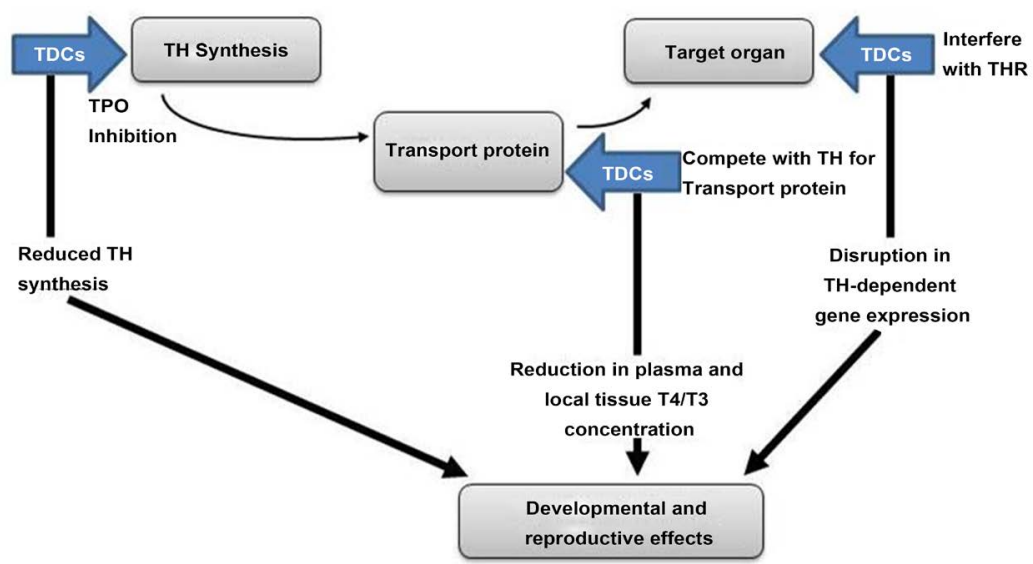

Figure 2. Major thyroid hormone system disruption by thyroid disrupting chemicals (TDCs). TDCs interfere with thyroid hormone synthesis through the inhibition of thyroperoxidase (TPO), an enzyme responsible for the production of thyroxine through the oxidation of iodide ion to form iodine for addition to tyrosine residues. Some TDCs have potency to compete with $\mathrm{TH}$ for $\mathrm{TH}$ transport protein, and also interfere with thyroid hormone receptor (THR) in the target cells to either activate or repress THR. TDCs action can result in reduced TH synthesis, reduction in Plasma and local tissue TH concentration, and disruption in thyroid hormone-dependent gene expression, to adversely affect growth, development and reproduction in humans and wildlife. 
Interestingly, these chemicals have been shown to interfere with the endocrine system through multiple pathways [15], and it is therefore less likely that TR agonist activity is not environmentally relevant as performance limitation of reporter gene assays based on cell line type is increasingly becoming more probable [6]. For instance, Kitamur et al. [37] previously demonstrated that tetrabromobisphenol A (TBBPA) and tetrachlorobisphenol A (TCBPA) had only TR-agonist activity using rat pituitary cell line assay (GH3. TRELuc), but later detected TR-antagonist activity with the hamster ovary cell line assay (CHO-K1) [23]. Similarly, the hydroxylated PCB metabolite (4-OH-PCB 106) previously reported to have only TR-antagonist potency with CV-1 cell based TH reporter gene assay [35], was not only revealed later to have TR-agonist activity with GH3. TRE-Luc assay, the response was also dose-dependent [17]. Additionally, Mengeling and Furlow [43] recently demonstrated in human hepatocarcinoma cell line (HuH7) and rat pituitary cell line (GH3. TRE-Luc) that TR activation or inhibition is cell type-dependent even when both cell lines were transfected with luciferase reporter gene. Further, while they observed permissive transactivation of luciferase reporter gene by retinoid agonist in rat pituitary cell line; the retinoid agonist, however, did not activate luciferase reporter gene in human hepatocarcinoma cell line.

\section{Future Perspective}

Thyroid disrupting activities with potential to interfere with TR is clearly a major mode of action of TDCs. This TR-mediated thyroid disruption is currently detected with TR binding assays and reporter gene assays, and only reporter gene assays are able to distinguish between TR-agonist and TR-antagonist activities. Currently, the reporter gene assays that are widely used, with their constituent cell lines, for the detection of (anti)thyroid activities in environmental water samples include GH3. TRE-Luc (rat pituitary cell line), TR $\beta$-CALUX (human bone osteosarcoma U2OS cell line), TR $\beta$-Gene-BLAzer (human embryonic kidney HEK 293T cell line), Yeast two-hybrid assay (yeast cell), and XL58-TRE-Luc (Xenopus laevis cell line) [6] [44] [45].

The development and use of TH reporter gene assays with endogenous thyroid functions related cell lines should therefore be considered as the rat pituitary cell line (GH3. TRE-Luc) has been observed to be particularly sensitive, especially to thyroid disrupting activities with TR agonist potency. Further, TH reporter gene assays based on thyroid function related cell line may also be developed to be used in pairs with assays of related cell line type where permissive transactivation of TR response element through TRs heterodimer partners by potential TDCs is suspected or detected.

\section{Conclusion}

Thyroid hormones play a leading role in organismal development involving almost all tissues of the body, and its disruption is a major threat to wildlife and 
humans. The development of novel thyroid function related in vitro assay cell lines, particularly for improved detection of thyroid disrupting activities involving THR signaling, is therefore a major research need. This is of critical importance to environmental risk assessment in the aquatic environment which serves as a sink to most toxic chemicals of anthropogenic origin considering that no specific biomarkers of exposure and effects of TDCs in intact organism has been identified, and the challenging performance limitation of cell lines of currently used in vitro assays in detecting TR agonist activity of TDCs.

\section{Conflicts of Interest}

The authors declare no conflicts of interest regarding the publication of this paper.

\section{References}

[1] Chen, X., Xu, S., Tan, T., Lee, S., Cheng, S.H., Lee, F.W., et al. (2014) Toxicity and Estrogenic Endocrine Disrupting Activity of Phthalates and Their Mixtures. International Journal of Environmental Research and Public Health, 11, 3156-3168. https://doi.org/10.3390/ijerph110303156

[2] Bergman, A., Heindel, J.J., Kasten, T., Kidd, K.A., Jobling, S., Neira, M., et al. (2013) The Impact of Endocrine Disruption: A Consensus Statement on the State of the Science. Environmental Health Perspective, 121, A104-A106. https://doi.org/10.1289/ehp.1205448

[3] Jugan, M., Levi, Y. and Blondeau, J. (2010) Endocrine Disruptors and Thyroid Hormone Physiology. Biochemical Pharmacology, 79, 939-947.

https://doi.org/10.1016/j.bcp.2009.11.006

[4] Rowdhwal, S.S.S. and Chen, J. (2018) Toxic Effects of Di-2-Ethylhexyl Phthalate: An Overview. BioMed Research International, 2018, Article ID: 1750368. https://doi.org/10.1155/2018/1750368

[5] Spaan, K., Haigis, A., Jana Weiss, J. and Legradi, J. (2019) Effects of 25 Thyroid Hormone Disruptors on Zebrafish Embryos: A Literature Review of Potential Biomarkers. Science of the Total Environment, 656, 1238-1249.

https://doi.org/10.1016/j.scitotenv.2018.11.071

[6] Leusch, F.D.L., Aneck-Hahn, N.H., Cavanagh, J.E., Pasquier, D.D., Hamers, T., Hebert, A., et al. (2018) Comparison of in Vitro and in Vivo Bioassays to Measure Thyroid Hormone Disrupting Activity in Water Extract. Chemosphere, 191, 868-875. https://doi.org/10.1016/j.chemosphere.2017.10.109

[7] Miller, M.D., Crofton, K.M., Rice, D.C. and Zoeller, R.T. (2009) Thyroid-Disrupting Chemicals: Interpreting Upstream Biomarkers of Adverse Outcomes. Environmental Health Perspectives, 117, 1033-1041. https://doi.org/10.1289/ehp.0800247

[8] Nahar, M.S. andDolinoy, D.C. (2018) Endocrine Disruptors and Critical Windows: Development and Disruption of the Thyroid Hormone Pathway in Early Life. In: McQueen, C.A., Ed., Comprehensive Toxicology, Elsevier, Oxford, 257-276. https://doi.org/10.1016/B978-0-12-801238-3.64214-9

[9] Hartung, T. and Daston, G. (2009) Are in Vitro Tests Suitable for Regulatory Use? Toxicological Sciences, 111, 233-237. https://doi.org/10.1093/toxsci/kfp149

[10] Escher, B.I., Allinson, M., Altenburger, R., Bain, P.A., Balaguer, P., Busch, W., et al. (2014) Benchmarking Organic Micropollutants in Wastewater, Recycled Water and 
Drinking Water with in Vitro Bioassays. Environmental Science \& Technology, 48, 1940-1956. https://doi.org/10.1021/es403899t

[11] Leusch, F.D.L., Neale, P.A., Hebert, A., Scheurer, M. and Schriks, M.C.M. (2017) Analysis of the Sensitivity of in Vitro Bioassays for Androgenic, Progestagenic, Glucocorticoid, Thyroid and Estrogenic Activity: Suitability for Drinking and Environmental Waters. Environment International, 99, 120-130. https://doi.org/10.1016/j.envint.2016.12.014

[12] Ishihara, A., Rahman, F.B., Leelawatwattana, L., Prapunpoj, P. and Yamauchi, K. (2009) In Vitro Thyroid Hormone-Disrupting Activity in Effluents and Surface Waters in Thailand. Environmental Toxicology and Chemistry, 28, 586-594. https://doi.org/10.1897/08-120.1

[13] Makinwa, T. and Uadia, P. (2017) Occurrence of Bisphenol A (BPA) in Ponds, Rivers and Lagoons in South-Western Nigeria and Uptake in Cat Fish Evidence of Environmental Contamination. Food and Public Health, 7, 1-6.

[14] Arukwe, A., Olufsen, M., Cicero, N. and Hansen, M.D. (2014) Effects on Development, Growth Responses and Thyroid-Hormone Systems in Eyed-Eggs and Yolk-Sac Larvae of Atlantic Salmon (Salmosalar) Continuously Exposed to 3,3',4,4'-Tetrachlorobiphenyl (PCB-77). Journal of Toxicology and Environmental Health, Part A, 77, 574-586. https://doi.org/10.1080/15287394.2014.887422

[15] Brueller, W., Inreiter, N., Boegl, T., Rubasch, M., Saner, S., Humer, F., et al. (2018) Occurrence of Chemicals with Known or Suspected Endocrine Disrupting Activity in Drinking Water, Groundwater and Surface Water, Austria 2017/2018. Journal of Land Management, Food and Environment, 69, 155-173. https://doi.org/10.2478/boku-2018-0014

[16] Gereben, B., Zavacki, A.M., Ribich, S., Kim, B.W., Huang, S.A., Simonides, W.S., et al. (2008) Cellular and Molecular Basis of Deiodinase-Regulated Thyroid Hormone Signaling. Endocrine Review, 29, 898-938. https://doi.org/10.1210/er.2008-0019

[17] Freitas, J., Cano, P., Craig-Veit, C., Goodson, M.L., Furlow, J.D. and Murk, A.J. (2011) Detection of Thyroid Hormone Receptor Disruptors by a Novel Stable in Vitro Reporter Gene Assay. Toxicology in Vitro, 25, 257-266. https://doi.org/10.1016/j.tiv.2010.08.013

[18] Heyland, A. and Moroz, L.L. (2005) Cross-Kingdom Hormonal Signaling: An Insight from Thyroid Hormone Functions in Marine Larvae. The Journal of Experimental Biology, 208, 4355-4361. https://doi.org/10.1242/jeb.01877

[19] Montano, M., Cocco, E., Guignard, C., Marsh, G., Hoffmann, L., Bergman, A., et al. (2012) New Approaches to Assess the Transthyretin Binding Capacity of Bioactivated Thyroid Hormone Disruptors. Toxicological Sciences, 130, 94-105. https://doi.org/10.1093/toxsci/kfs228

[20] Miyazaki, W., Iwasaki, T., Takeshita, A., Tohyama, C. and Koibuchi, N. (2008) Identification of the Functional Domain of Thyroid Hormone Receptor Responsible for Polychlorinated Biphenyl-Mediated Suppression of Its Action in Vitro. Environmental Health Perspective, 116, 1231-1236. https://doi.org/10.1289/ehp.11176

[21] Crofton, K.M., Craft, E.S., Hedge, J.M., Gennings, C., Simmons, J.E., Carchman, R.A., et al. (2005) Thyroid-Hormone-Disrupting Chemicals: Evidence for Dose-Dependent Additivity or Synergism. Environmental Health Perspectives, 113, 1549-1554. https://doi.org/10.1289/ehp.8195

[22] Marchesini, G.R., Meulenberg, E., Haasnoot, W., Mizuguchi, M. and Irth, H. (2006) Biosensor Recognition of Thyroid-Disrupting Chemicals Using Transport Proteins. Analytical Chemistry, 78, 1107-1114. https://doi.org/10.1021/ac051399i 
[23] Kitamura, S., Kato, T., Iida, M., Jinno, N., Suzuki, T., Ohta, S., et al. (2005) Anti-Thyroid Hormonal Activity of Tetrabromobisphenol A, a Flame Retardant, and Related Compounds: Affinity to the Mamalianthyroid Hormone Receptor, and Effect on Tadpole Metamorphosis. Life Science, 76, 1589-1601. https://doi.org/10.1016/j.lfs.2004.08.030

[24] Stavreva, D.A., Varticovski, L., Levkova, L. George, A.A., Davis, L., Pegoraro, G., et al. (2017) Novel Cell-Based Assay for Detection of Thyroid Receptor Beta-Inter-Acting Environmental Contaminants. Toxicology, 368-369, 69-79.

https://doi.org/10.1016/j.tox.2016.08.012

[25] Murata, T. and Yamauchi, K. (2008) 3,3,5-Triiodo-L-Thyronine-Like Activity in Effluents from Domestic Sewage Treatment Plants Detected by in Vitro and in Vivo Bioassays. Toxicology and Applied Pharmacology, 226, 309-317. https://doi.org/10.1016/j.taap.2007.09.003

[26] Jugan, M.L., Oziol, L., Bimbot, M., Huteau, V., Tamisier-Karolak, S., Blondeau, J.P., et al. (2009) In Vitro Assessment of Thyroid and Estrogenic Endocrine Disruptors in Wastewater Treatment Plants, Rivers and Drinking Water Supplies in the Greater Paris Area (France). Science of the Total Environment, 407, 3579-3587. https://doi.org/10.1016/j.scitotenv.2009.01.027

[27] Li, N., Wang, D., Zhou, Y., Ma, M., Li, J. and Wang, Z. (2010) Dibutyl Phthalate Contributes to the Thyroid Receptor Antagonistic Activity in Drinking Water Processes. Science of the Total Environment, 44, 6863-6868. https://doi.org/10.1021/es101254c

[28] Li, N., Ma, M., Rao, K. and Wang, Z. (2011) In Vitro Thyroid Disrupting Effects of Organic Extracts from WWTPs in Beijing. Journal of Environmental Sciences, 23, 671-675. https://doi.org/10.1016/S1001-0742(10)60461-5

[29] Shi, W., Hu, X., Zhang, F., Hu, G., Hao, Y., Zhang, X., et al. (2012) Occurrence of Thyroid Hormone Activities in Drinking Water from Eastern China: Contribution of Phthalate Esters. Environmental Science and Technology, 46, 1811-1818. https://doi.org/10.1021/es202625r

[30] Shi, W., We, S., Hu, X., Hu, G., Chen, C., Wang, X., et al. (2013) Identification of Thyroid Receptor Ant/Agonists in Water Sources Using Mass Balance Analysis and Monte Carlo Simulation. PLOS ONE, 8, e73883.

https://doi.org/10.1371/journal.pone.0073883

[31] Shi, W., Deng, D., Wang, Y., Hu, G., Guo, J., Zhang, X., et al. (2016) Causes of Endocrine Disrupting Potencies in Surface Water in East China. Chemosphere, 144, 1435-1442. https://doi.org/10.1016/j.chemosphere.2015.09.018

[32] Shi, W., Wang, X., Hu, G., Hao, Y., Zhang, X., Liu, H., et al. (2011) Bioanalytical and Instrumental Analysis of Thyroid Hormone Disrupting Compounds in Water Sources along the Yangtze River. Environmental Pollution, 159, 441-448. https://doi.org/10.1016/j.envpol.2010.10.023

[33] Shi, W., Zhang, F.X., Hu, G.J., Hao, Y.Q., Zhang, X.W., Liu, H.L., et al. (2012) Thyroid Hormone Disrupting Activities Associated with Phthalate Esters in Water Sources from Yangtze River Delta. Environment International, 42, 117-123. https://doi.org/10.1016/j.envint.2011.05.013

[34] Kassotis, C.D., Iwanowicz, L.R., Akobc, D.M., Cozzarelli, I.M., Mumfordc, A.C., Orem, W.H., et al. (2016) Endocrine Disrupting Activities of Surface Water Associated with a West Virginia Oil and Gas Industry Wastewater Disposal Site. Science of the Total Environment, 557-558, 901-910.

https://doi.org/10.1016/j.scitotenv.2016.03.113 
[35] Iwasaki, T., Miyazaki, W., Takeshita, A., Kuroda, Y. and Koibuchi, N. (2002) Polychlorinated Biphenyls Suppress Thyroid Hormone-Induced Transactivation. Biochemical and Biophysical Research Communications, 299, 384-388. https://doi.org/10.1016/S0006-291X(02)02659-1

[36] You, S., Gauger, K.J., Bansal, R. and Zoeller, R.T. (2006) 4-Hydroxy-PCB106 Acts as a Directthyroid Hormone Receptor Agonist in Rat GH3 Cell. Molecular and Cellular Endocrinology, 257-258, 26-34. https://doi.org/10.1016/j.mce.2006.06.009

[37] Kitamura, S., Jinno, N., Ohta, S., Kuroki, H. and Fujimoto, N. (2002) Thyroid Hormonal Activity of the Flame Retardants Tetrabromobisphenol A and Tetrachlorobisphenol A. Biochemical and Biophysical Research Communications, 293, 554-559. https://doi.org/10.1016/S0006-291X(02)00262-0

[38] Kudo, Y. and Yamauchi, K. (2005) In Vitro and in Vivo Analysis of the Thyroid Disrupting Activities of Phenolic and Phenol Compounds in Xenopuslaevis. Toxicological Sciences, 84, 29-37. https://doi.org/10.1093/toxsci/kfi049

[39] Hinther, A., Bromba, C.M., Wulff, J.E. and Helbing, C.C. (2011) Effects of Triclocarban, Triclosan, and Methyl Triclosan on Thyroid Hormone Action and Stress in Frog and Mammalian Culture Systems. Environmental Science \& Technology, 45, 5395-5402. https://doi.org/10.1021/es1041942

[40] Tonacchera, M., Pinchera, A., Dimida, A., Ferrarini, E., Agretti, P., Vitti, P., et al. (2004) Relative Potencies and Additivity of Perchlorate, Thiocyanate, Nitrate, and Iodideon the Inhibition of Radioactive Iodide Uptake by the Human Sodium Iodide Symporter. Thyroid, 14, 1012-1018. https://doi.org/10.1089/thy.2004.14.1012

[41] Urbansky, E.T. (2002) Perchlorate as an Environmental Contaminant. Environmental Science and Pollution Research, 9, 187-192.

https://doi.org/10.1007/BF02987487

[42] Perez, A.L., De Sylor, M.A., Slocombe, A.J., Lew, M.G., Unice, K.M. and Donovan, E.P. (2013) Triclosan Occurrence in Freshwater Systems in the United States (1999-2012): A Meta-Analysis. Environmental Toxicology and Chemistry, 32, 1479-1487. https://doi.org/10.1002/etc.2217

[43] Mengeling, B.J. and Furlow, J.D. (2015) Pituitary Specific Retinoid-X Receptor Ligand Interactions with Thyroid Hormone Receptor Signaling Revealed by High Throughput Reporter and Endogenous Gene Responses. Toxicology in Vitro, 29, 1609-1618. https://doi.org/10.1016/j.tiv.2015.06.018

[44] Sugiyama, S., Shimada, N., Miyoshi, H. and Yamauchi, K. (2005) Detection of Thyroid System-Disrupting Chemicals Using in Vitro and in Vivo Screening Assays in Xenopuslaevis. Toxicological Sciences, 88, 367-374. https://doi.org/10.1093/toxsci/kfi330

[45] Li, J., Ma, M. and Wang, Z.A. (2008) A Two-Hybrid Yeast Assay to Quantify the Effects of Xenobiotics on Thyroid Hormone-Mediated Gene Expression. Environmental Toxicology and Chemistry, 22, 159-167. https://doi.org/10.1897/07-054.1 


\section{Abbreviation}

TDCs: Thyroid disrupting chemicals

THR/TR: Thyroid hormone receptor/Thyroid receptor

T4: Thyroxine

T3: Triiodothyronine

TRH: Thyrotropin-releasing hormone

TSH: Thyroid stimulating hormone

DIO: Deiodinase

TTR: Transthyretin

TBG: Thyroxine binding globulin

RBA: Radio-ligand binding assay

TRE: Thyroid hormone response element 